DOI: 10.32347/2412-9933.2020.44.100-104

УДК 519.68

\title{
Tsiutsiura Mykola
}

DSc (Eng.), Associate Professor, Department of Information Technology, orcid.org/0000-0003-4713-7568

Kyiv National University of Construction and Architecture, Kyiv

\section{Yerukaiev Andrii}

$\mathrm{PhD}$ (Eng.), Department of Information Technology, orcid.org/0000-0002-9956-3713

Kyiv National University of Construction and Architecture, Kyiv

\section{Prystailo Mykola}

PhD (Eng.), Associate Professor, Department of Applied Mechanics, orcid.org/0000-0003-3151-4680

Kyiv National University of Construction and Architecture, Kyiv

\section{Kuleba Mykola}

Graduate of the Department of Information Technologies, orcid.org/0000-0003-4713-7568

Kyiv National University of Construction and Architecture, Kyiv

\section{MODELS AND METHODS OF ARTIFICIAL INTELLIGENCE FOR CREATING A COMPUTER CREATIVITY PRODUCT}

\begin{abstract}
Today, information technology is used in all spheres of human activity, it can greatly simplify the processes that require routine, physical, computational tasks in people's everyday life and in their production activities. Models and methods that form the basis of information technology impacted by continuous improvement, and this gives more and more new opportunities where they could be applied in practice. Particularly in such areas as artificial intelligence, because each person, for example, uses such indisputable and simply necessary assistants as large electrical appliances that have an intellectual component (refrigerators, washing machines, etc.). And the evolution of artificial intelligence does not stop there, and here we must mention such an important area of human life as recreation. This type of pastime means its classic manifestation, without the use of expensive gadgets, watching various programs on TV or the Internet and even not doing sports at home or outdoors. We mean an intellectual holiday, based on the usual favorite art book, which is read with the sounds of a pleasant melody, with beautiful illustrations, and now, by the way, for some time in scientific circles there is talk of using models and methods to create a creative product. by which is meant a written poem, a literary prose work, a painted picture, and so on. That is, the performance of those tasks that are traditionally attributed only to geniuses, artists throughout the history of human existence. In this article it is offered to consider directions in which researches in creation of a creative product by computers (machines) at use of methods of artificial intelligence take place today. Also briefly described approaches that describe the most advanced ideas for realizing the creative potential of computer machines.
\end{abstract}

Key words: artificial intelligence; machine creativity; heuristic programming; semantic network; frame

\section{Introduce}

In scientific works devoted to the machine creativity study, this term means a program imitation of the process of creating works that can be considered the results of creative activity. Whereas creativity in the general case is a process of creating something new. Accordingly, the creative process is the tasks resolution for which detection algorithms are currently unknown $[1 ; 3]$.

Creativity has not only indisputable uniqueness, but also generality, regularity, which can be explored and reproduced using models and methods of artificial intelligence.

Works that are the result of the creative process include $[2 ; 6 ; 10]$ :

1) theme, type of work, a set of elements (words, notes, etc.) from which the work is built;
2) patterns, rules and restrictions (rules of poetry, etc.);

3) "creative discoveries" (deviations from the rules), which are random

Thus, if we use the Venn diagrams to represent these three definitions, then machine art will be at the intersection of creativity, the creative process and artificial intelligence. Figure 1 shows this model.

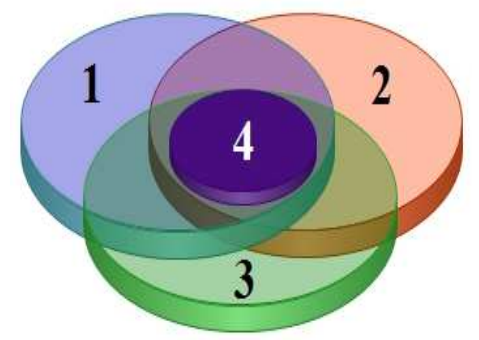

Figure 1 - Venn diagram of machine learning components 


\section{The purpose of the article}

The purpose of the article is to present the main areas that are currently the most common and researched for the implementation of machine learning. In addition, the authors aim to present a description of semantic networks and frames, which are methods of artificial intelligence, the use of which is present in the knowledge base in almost every area that is programmatically implemented in machine art.

\section{Main material presenting}

To date, the most common areas of research in machine creativity are the following $[7,10]$ :

- literary works of art:

a) prose;

b) poems.

- music;

- artistic perception.

Let us consider each of them in more detail.

In order to form an information system that should generate a literary prose work, it is necessary to take into account the following components [1, 4]:

1) initial plan describing:

a) the type of plot;

b) the system of actors;

c) exposure.

2) situational description of the characters

3) locus structure that describes the places where the characters:
a) ive;
b) occur;
c) act.

At figure 2 their interaction is presented.

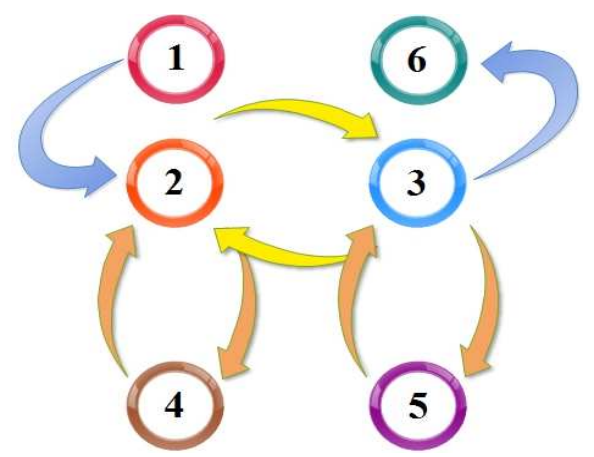

Figure 2 - The main components of the information system that forms a literary prose work

At figure 2 numbers marked:

1) the initial plan;

2) characters;

3) locus structure;

4) personal characteristics;

5) a description loci;

6) collection and issuance of text

Creating a meaningful poem requires knowledge of grammar, metrics and rhythm. In this case, the semantics should be formed from the grammar and imagination of the reader. Based on this, the following directions are performed in the study of poetry by methods and models of artificial intelligence [9-12]:

1) analysis of meter and rhythm;

2) analysis of stylistic characteristics;

3) creating a catalog of rhymes;

4) synthesis of poetic texts.

In order to create at least one verse line, the program must contain a dictionary in which each word must be described using information about the meter (number of syllables, stress), rhyme (feminine, masculine) and grammar (part of speech and sentence).

Areas in the study of music are as follows $[5 ; 13]$ :

1) creating melodies of a given style;

2) creating an accompaniment;

3) harmonization of melodies;

4) check the harmonization tasks by computer.

By example of the program structure, which generates melodies from intonations, let us consider the general approach to an information system building that meets the criteria of machine creativity $[2 ; 4]$ :

1) input data - is an array of melodies that are input to the computer for analysis;

2) database - is an alphabet (musical notation) and data of melodies analysis from the output block;

3) knowledge base is a set of programmed rules;

4) control system - a component of the IS, which forms a typical structure in the form of a semantic network or frame;

5) communication in natural language - is the presentation of machine results (melodies with its parameters and typical structure).

As can be seen from the structure of the program, it is quite similar to one of the known and used models of artificial intelligence - expert systems, whose structure is presented in Figure 3 [1; 3; 9].

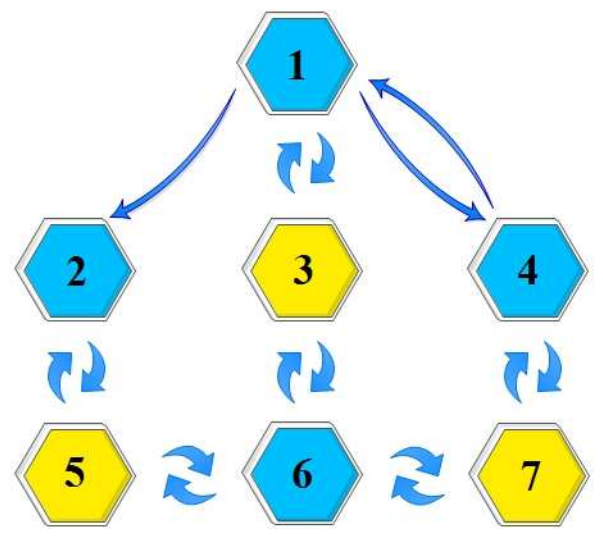

Figure 3 - Structure of expert systems

At figure 3 numbers marked:

1) user interface;

2) dialogue analysis block;

3) block of explanations;

4) block of knowledge accumulation; 
5) working memory;

6) solver;

7) knowledge base.

In order to evaluate the result of the creative work of the information system, its beauty, success, emotionality, sensuality, what imagination the user evokes, the following types of research are performed in the following areas $[2 ; 8]$ :

1) formalization of the jury's work;

2) modeling of perception analysis;

3) scaling of aesthetic evaluations;

4) measurement of styles.

Heuristic programming is an algorithmic description of people's actions that solves problems where it is impossible to describe the procedure for solving them. This technology uses knowledge of human behavior in solving creative problems, but does not use knowledge of the properties and features of the subject area in which the problem is to be solved.

However, there is a way to impose restrictions on the subject area (ie knowledge of the subject area under consideration) by constructing in the computer memory a relatively complete model of the subject area together with the possible relationships between its elements.

This can be done using artificial intelligence methods, namely semantic networks and frames.

The semantic network is a model of the subject area, presented in the form of a graph, the vertices of which are concepts, and arcs (edges) - the relationship between them.

The most common types of semantic relationships are the following [1-3]:

1) part - whole (scene in piece of art is a part of the plot);

2) subclass - class (the novel is an epic of art in creation);

3) A is on B (young girl dancing alone on the floor);

4) cause - consequence;

5) earlier, later.

A Rastier graph is a type of semantic network used to represent events and build relationships around verbs.

The main components of a Rastier graph or a graph with a verb in the center are the following relations: agent, object, co-agent, and so on.

An example of a semantic model describing a sentence with artistic meaning "Insomnia is the mockery of the night over a person" is presented at Figure 3.

A frame is a model of the subject area used to represent a stereotypical situation of visual perception. A component of the frame is the script, which is a kind of structure of human consciousness. There are the following levels of scenario structure $[2 ; 4 ; 9]$ :

1) surface-syntactic frame;

2) surface-semantic frame;

3) thematic frame;

4) the frame of the story.

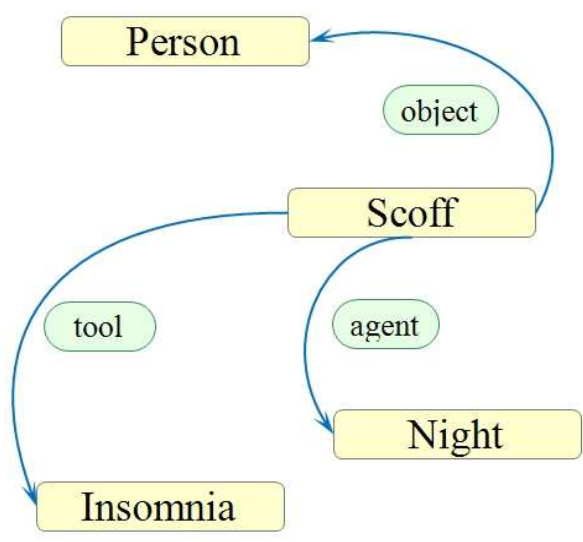

Figure 3 - Example of a semantic network

An example describing a sentence with artistic meaning "Fortune is not only blind, but also blinds its favorits" using a surface-syntactic frame or valence frame, is presented in Figure 4.

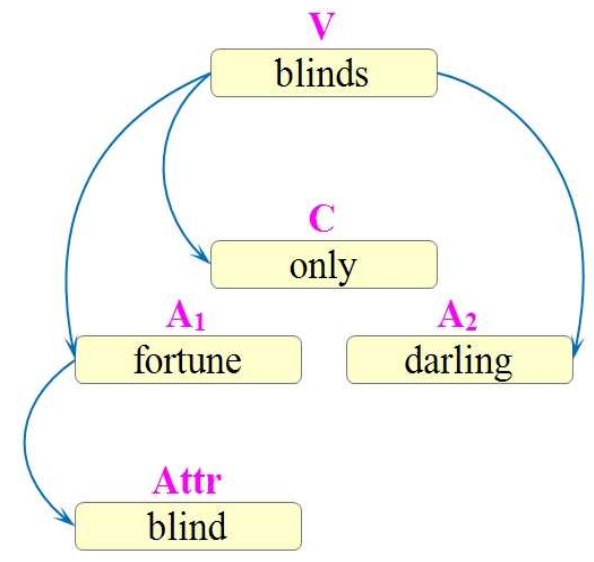

Figure 4-Example of a frame

At Figure 4 there are symbolic symbols, which mean the following:

- V - verb node;

- A1, A2 - first and second actant, respectively;

- C - sirkonstant;

- Attr - is an attribute.

\section{Conclusion}

In this article the main directions of research of machine (computer) creativity were considered.

Examples describing the structure of programs of some of the considered directions are given due to analytical methods can do little to help develop them.

Artificial intelligence is proposed, the models and methods of which are best suited to solve the problem.

The main purpose of this area of computer science is the processing and storage of knowledge in computer memory, as the knowledge base is one of the mandatory elements of programs that simulate machine creativity, were demonstrated by specific examples of models of artificial intelligence knowledge: semantic networks and frames. 


\section{References}

1. Tsiutsiura, Mykola, Yerukaiev, Andrii \& Lyashchenko, Tamara, (2020). Balancing the educational space. Main elements of a comprehensive model for assessing the quality of education. Management of Development of Complex Systems, 43, 142-147, dx.doi.org \10.32347/2412-9933.2020.43.142-147.

2. Tsiutsiura, Svitlana, Bebeshko, Bohdan \& Khorolska, Karyna, (2020). VR-technology as a modern architecture tool. Management of Development of Complex Systems, 42, 69-74, dx.doi.org\10.32347/2412-9933.2020.42.69-74.

3. Tsiutsiura, Mykola, Yerukaiev, Andrii, Hots, Vladyslav \& Kostyshyna, Nataliia, (2019). Implementation of a genetic algorithm using product rules. Management of Development of Complex Systems, 39, 64-68. dx.doi.org $110.6084 / \mathrm{m} 9$.figshare.11340653.

4. Tsiutsiura, Mikola, \& Yerukaiev, Andrii, (2018). Application of the genetic algorithm for the formation of the membership function of fuzzy sets. Management of Development of Complex Systems, 36, 71-75.

5. Czukanova, N.I., Majkov, K.A., (2017). Technology for developing expert systems in the language Visual Progolog 7.5. Moscow: KURS, 256.

6. Vasenina, V.A., (2009). The mathematical foundations of artificial intelligence: the theory of LP-structures for the construction and study of knowledge models of the productive type. Moscow: MCzNMO, 304.

7. Ruchkin, V.N., Fulin, V.A., (2009). Universal artificial intelligence and expert systems. St. Petersburg: BKhV-Peterburg, 240.

8. Nikolajchuk, O.A., Pavlov, A.I., \& Yurin, A.Y., (2010). Component approach: production expertise system module. Software Products and Systems, 3, 41-44.

9. Kyivska, Kateryna, Tsiutsiura, Svitlana \& Kuleba, Mykola, (2020). Analysis of application of artificial intelligence in BIM-technology. Management of Development of Complex Systems, 43, 97-103, dx.doi.org\10.32347/2412- 9933.2020.43.97-103

10. Mytsel, A., (2005). The use of fuzzy linguistic models in the development of a municipal development strategy. News of Tomsk Polytechnic University, 4(308), 177-182.

11. Leonenkov, A., (2014). Fuzzy simulation in the environment MATLAB and fuzzyTECH. St. Petersburg, Russia: BKhV - Peterburh. Telekom.

12. Rutkovskaia, D., (2013). Neural networks, genetic algorithms and fuzzy systems. Moscow, Russia: Horiachaia lynyia -

13. Shtovba, S., (2007). Designing fuzzy systems by means MATLAB. Moscow, Russia: Horiachaia lynyia - Telekom.

Стаття надійшла до редколегї 02.09.2020

\section{Цюцюра Микола Ігорович}

Доктор технічних наук, доцент, професор кафедри інформаційних технологій, orcid.org/0000-0003-4713-7568

Київський національний університет будівництва і архітектури, Київ

Срукасв Андрій Віталійович

Кандидат технічних наук, доцент кафедри інформаційних технологій, orcid.org/0000-0002-9956-3713

Київський національний університет будівництва і архітектури, Київ

\section{Пристайло Микола Олексійович}

Кандидат технічних наук, доцент, доцент кафедри будівельних машин, orcid.org/0000-0003-3151-4680

Київський національний університет будівництвва і архітектури, Київ

Кулеба Микола Борисович

Аспірант кафедри інформаційних технологій, orcid.org/0000-0003-4713-7568

Київський національний університет будівництвв і архітектури, Київ

\section{МАШИННА ТВОРЧІСТЬ. ОСНОВНІ НАПРЯМИ ДОСЛІДЖЕННЯ}

Анотація. На сьогодні інформаційні технології застосовуються в усіх сферах людської діяльності. Це дає змогу значно спростити процеси, щуо вимагають виконання рутинних, фізичних, обчислювальних задач у повсякденному житті людей та у їхній виробничій діяльності. Моделі і методи, щэо складають основу інформаційних технологій, відчувають на собі вплив постійного вдосконалення, що дає все більше нових можливостей для застосовування їх на практиці. Особливо ие стосується штучного інтелекту, адже кожна людина користується в побуті такими необхідними помічниками, як великі електроприлади, щэо мають в собі інтелектуальну складову (холодильники, пральні машини тощо). Проте на цьому еволюиія штучного інтелекту не зупинятться, тож треба згадати про таку важливу сферу життя людини, як відпочинок. Як такий вид проведення часу розуміється його класичний прояв: без використання дорогих ігрових гаджетів, перегляду різноманітних телевізійних програм, інтернету, без виконання спортивних тренувань вдома 
чи на свіжсму повітрі. Йдеться про інтелектуальний відпочинок, основою якого є звичайна улюблена художня книжка, яка читається під звуки приємної мелодії з переглядом красивих ілюстрачій. Отже, вже деякий час в наукових колах йде розмова про застосування моделей і методів для створення творчого продукту, як-от: написаний віри, художній прозовий твір, намальована картина тощо. Тобто виконання тих задач, які традиційно приписуються тільки геніям, митиям за всю історію людського існування. У статті пропонується розглянути напрями, за якими зараз відбуваються дослідження щьодо створення творчого продукту комп'ютерами (машинами) при використанні методів штучного інтелекту. Також стисло описано підходи найбільш передових ідей для реалізачії творчого потенціалу комп'ютерівмашин.

Ключові слова: итучний інтелект; машинна творчість; евристичне програмування; семантична мережа; фрейм

\section{Link to the article}

APA Tsiutsiura, Mykola, Yerukaiev, Andrii, Prystailo, Mykola, \& Kuleba, Mykola, (2020). Models and methods of artificial intelligence for creating a computer creativity product. Management of Development of Complex Systems, 44, 100 - 104, dx.doi.org\10.32347/2412-9933.2020.44.100-104.

ДСТУ Цюцюра, М. І., Єрукаєв А. В., Пристайло М. О., Кулеба М. Б. Машинна творчість. Основні напрями дослідження. Управління розвитком складних систем. Київ, 2020. № 44. С. 100 - 104, dx.doi.org\10.32347/2412-9933.2020.44.100-104. 